\title{
O teologiji štovanja relikvije Predragocjene Krvi Kristove
}

\author{
Ivica Raguž*
}

\begin{abstract}
Sažetak
Članak tumači teologiju štovanja relikvije Predragocjene Krvi Kristove u hrvatskom svetištu Ludbregu, kao i ostalim svetištima u Katoličkoj crkvi. Za teološko razumijevanje pobožnosti Kristovoj krvi od velikoga je značenja katolički nauk o transsupstancijaciji. Stoga se u prvom dijelu članka prikazuje nauk o transsupstancijaciji, pri čemu se uzimaju u obzir kritička promišljanja i drukčiji pristup tomu nauku francuskoga filozofa Jean-Luca Mariona. Drugi dio bavi se pojedinim teološkim teorijama o Kristovoj krvi te se potom u nekoliko točaka sažima teologija štovanja Krvi Kristove. Riječ je o teologiji koja štovanje Kristove krvi smješta unutar teologije ikone. Obrazlaže se da takvo ikoničko štovanje Kristove krvi u Ludbregu i u drugim svetištima u današnje vrijeme ima veliku važnost za razumijevanje $i$ življenje euharistije.

Ključne riječi: transsupstancijacija, Kristova krv, Jean-Luc Marion, euharistija, Ludbreg
\end{abstract}

\section{Uvod}

»Euharistijski Krist točno je isti onaj koji je razgovarao s apostolima. No, oni su ga gledali izvana prema unutra, dok ga mi, ako se tako može reći, zadržavamo iznutra prema vani. [...] Krist nam je tijekom svojega života predavao samo svoje ruke ili svoje lice, ono izvanjsko, a ne svoju supstanciju. Euharistijski Krist pak povlači svoje ruke i želi nam predati svoje srce i svoju supstanciju, u kojoj se nalazi sve ostalo. ${ }^{1}$ Tim riječima francuski književnik Paul Claudel opisuje svoju vjeru u realnu prisutnost Isusa Krista u euharistiji. Čini se da su te Claudelove misli u potpunoj suprotnosti sa svetištem Predragocjene Krvi Kristove u Ludbregu, ali i sa svim ostalim svetištima koja čuvaju krv Isusa Krista. Dok Claudel naglašava da nam Kristove ruke, lice, a dodali bismo, i njegova krv ostaje skrivena, svetište Predragocjene Krvi Kristove, tako nam barem sam naziv svetišta sugerira, uka-

* Izv. prof. dr. sc. Ivica Raguž, Katolički bogoslovni fakultet u Đakovu. Sveučilište Josipa Jurja Strossmayera u Osijeku. Adresa: Petra Preradovića 17, p. p. 54, 31000 Osijek, Hrvatska. E-pošta: ivica.raguz@os.t-com.hr

1 Citat kod X. Tilliette, Eucaristia e filosofia, Brescia, 2008., str. 146. 
zuje na čudo, na činjenicu da se tu može vidjeti sama Kristova krv. Tako dobivamo dojam da ludbreško svetište i druga svetišta nisu samo u suprotnosti s Claudelovom postavkom, nego sa samom euharistijom. Dok u euharistiji ne vidimo Kristovu krv, koja ostaje skrivena pod prilikom vina, u svetištu Predragocjene Krvi Kristove gledamo samu krv Kristovu. Nevidljivu gledamo i pijemo, a vidljivu samo gledamo. Ne čini li nam se da štovanje krvi Kristove i samo svetište ne ugrožava samu euharistiju, jer naizgled nudi više od same euharistije? Kako je to moguće da se mimo euharistije, koja je »izvor i vrhunac cjelokupnoga života Crkve«, događa nešto veće i od same euharistije? Ako je krv u svetištu stvarna Kristova krv, kako razumjeti to da Krist uz euharistiju daje još svoju stvarnu krv? Ako krv Kristova u svetištu i drugim svetištima ipak nije stvarna Kristova krv, kako je onda tumačiti? O kojoj je onda krvi riječ i koja je njezina uloga? A ako je zaista krv Kristova, koje je njezino značenje?

Koliko god nam se ta i slična pitanja činila novima, ona uopće nisu nova. Naime, u kasnom srednjovjekovlju 14. i 15. stoljeća, u stoljećima koja možemo nazvati stoljećima krvi Kristove, vodile su se najveće rasprave o Kristovoj krvi, o njezinu teološkom značenju, o mogućnostima pojavka na zemlji, o štovanju te iste krvi itd. Ovim člankom pokušat ćemo ukratko opisati navedene rasprave i dati svoje teološko razumijevanje čuda krvi Kristove u mnogobrojnim svetištima. No, prije nego se pozabavimo tom tematikom, u prvom dijelu izlaganja prikazat ćemo u temeljnim odrednicama katolički nauk o transsupstancijaciji, pri čemu ćemo se posebno zadržati na pojmu supstancije koja će nam poslužiti da bolje teološki promotrimo značenje i poruku čuda krvi Kristove u Ludbregu.

\section{Katolički nauk o transsupstancijaciji}

Nauk o transsupstancijaciji pojavio se u katoličkoj teologiji kao pokušaj da se ispravno promišlja Kristova prisutnost u euharistiji onkraj dvaju ekstrema: ekstremnog realizma i ekstremnog simbolizma. Kako ističe Tridentski koncil, taj se izričaj čini »vrlo prikladnim« (DH 1652) da se izrazi otajstvo realne prisutnosti Isusa Krista u euharistiji. Na taj način Koncil samo sažima ono što je bit svakoga dogmatskoga izričaja, a on se sastoji ne toliko u pozitivnom definiranju i određivanju, koliko u negativnom razgraničenju. Dogma, pa tako i nauk o transsuspstancijaciji, ima »značenje graničnog ukazivanja, geste koja upućuje na ono što nije moguće imenovati $\ll^{2}$ te na taj način postavlja kriterije kako ne bismo trebali misliti određeni sadržaj vjere. No, i tako shvaćen nauk o transsupstancijaciji postao je problematičan. S pojavom protestantizma shvaćen je kao neprihvatljiv način ovladavanja Bogom u sakramentima, kao nedijalektički govor o prisutnosti Boga bez eshatološke svijesti njegova »još ne«, kao reduciranje euharistije na objektivističku i statičnu djelatnost bez dinamične usmjerenosti prema osobi Isusa Krista, kao monofizitistička tendencija nauštrb čovještva Isusa Krista itd. Stoga se i moderna katolička teologija također pokušala distancirati 
od transsupstancijacije, predlažući druge teorije, primjerice transsignifikacije i transfinalizacije itd. ${ }^{3}$ I u modernoj filozofiji pojam transsupstancijacije također biva kritiziran. Spomenut ćemo ukratko kritiku francuskoga filozofa Jean-Luca Mariona. Njegova će nam kritika poslužiti da jasnije prikažemo katolički nauk o transsupstancijaciji, koji nam se čini i dalje »vrlo prikladnim« pojmom da se izrekne otajstvo Kristove realne prisutnosti u euharistiji.

Jean-Luc Marion kritizira nauk o transsupstancijaciji unutar svojega fenomenološkog pristupa euharistiji. ${ }^{4}$ Ključna teza Marionova fenomenološkog razmatranja o euharistiji jest događanje fenomena kao »davanje bez zadrške, sve do predavanja «. Prema Marionu, nauk o transsupstancijaciji upravo to sprječava. ${ }^{5}$ Naime, supstancija je ono što je skriveno, što se ne vidi, a time se ne pokazuje. Ne pokazujući se, ne daje se. Ostaje »stvar u sebi«. Premda Marion izričito to ne spominje u svojem tekstu, jasno se može zaključiti da se transsupstancijacija za francuskoga filozofa protivi samoj biti kršćanske vjere u Boga koji je Bog ljubavi. A ljubav je upravo to »davanje bez zadrške, sve do predavanja«, tako da je transsupstancijacija u svojoj statičnosti i skrivenosti supstancije zapravo oprečna samoj ljubavi. S druge pak strane, nauk o transsupstancijaciji također ne oblikuje naša osjetila, ne mijenja ih, jer se supstancija ne »očituje«. Naša osjetila ostaju nedodirnuta, premda bi to trebao biti temeljni smisao svakoga sakramenta, pa tako i euharistije. Stoga Marion predlaže da se pojam supstancije napusti i za sakramente, odnosno euharistiju tumači unutar fenomenološke metode. Radi se o tome da jedino fenomenološka metoda najprikladnije omogućuje razumijevanje euharistije kao »davanja bez zadrške, sve do predavanja«.

Naime, Marion shvaća fenomen kao pokazivanje koje je uvijek i davanje, jer se »ništa ne pokazuje, a da se pritom nije dalo«. ${ }^{6}$ Riječ je o dvostrukoj danosti: daje se samo pojavljivanje i daje se ono što se pojavljuje. ${ }^{7}$ Imajući na umu bitnu razliku između fenomena kao takvih i same euharistije te koristeći metodu analogije, ${ }^{8}$ Marion utvrđuje sličnu strukturu u samoj euharistiji. I u euharistiji, kao fenomenu, pokazuje se nešto i time se daje. Ono se daje tako što se pokazuje i pokazuje se tako što se daje. Dakako, postavlja se pitanje kako je moguće misliti da kruh i vino mogu pokazivati, odnosno da se Isus Krist može pokazivati-davati po kruhu i vinu. Oslanjajući se na Martina Heideggera, Marion tvrdi da se nijedna stvar ne može i ne smije reducirati na svoju uobičajenu uporabu, na svoju »priručnost«. Svaka stvar u sebi krije više od svoje uporabljivosti, priručnosti, tako da se unutar

3 Tako primjerice E. Schillebeeckx, Die eucharistische Gegenwart. Zur Diskussion über die Realpräsenz Düsseldorf 1968. Papa Pavao VI. u enciklici Mysterium fidei odbacio je obje teorije, i transsignifikaciju i transfinalizaciju (MF 11). Više o tome vidi A. Starić, Teološko tumačenje euharistijske Kristove prisutnosti, u: Bogoslovska smotra 2-3 (1981), str. 252-255.

4 J.-L. Marion, La fenomenalità del sacramento: essere e donazione, u: N. Reali (prir.), Il mondo del sacramento. Teologia e filosofia a confronto, Milano, 2001, str. 134-154.

5 Isto, str. 139-140.

6 Isto, str. $147 \mathrm{ss}$.

7 Isto.

8 Naime, euharistija pretpostavlja Božju intencionalnost, dakle prekomjernost i zasićenost intuicije koja se ne da svesti na pojmove, kao što to činimo kod uobičajenih objekata. Vidi Isto, str. 149s. 
fenomenološke metode može i treba dopustiti da kruh i vino u euharistiji također dobiju novo značenje. Fenomenologija treba računati s mogućnošću da se ono što se pokazuje u kruhu i vinu, u ostalim sakramentima može tako radikalno pokazivati da u tom pokazivanju pokazuje »sve ono što treba dati da se vidi «. ${ }^{9}$ To značenje može dati samo onaj koji je u sebi samom ostvario i prekomjerno dovršio bit same fenomenologije, kao »davanje bez zadrške sve do predavanja «, a to je Isus Krist, njegova kenoza, predanost na križu u Duhu Svetom. Tako, prema Marionu, jedino fenomenološka metoda uspijeva biti na tragu ono što se događa u samoj euharistiji, a to je »davanje bez zadrške, sve do podavanja.«

Ne ulazeći u daljnju analizu Marionova poimanja euharistije ${ }^{10}$, takva kritika nauka o transsupstancijaciji stvara puno veće probleme nego što ih razrješava. Istaknut ćemo samo dva problematična vida. Prvo, ništa se ne govori o tome u kakvom su odnosu ono što se pojavljuje i sam pojavak, odnosno kruh-vino i nevidljiva milost. Je li pojavak očuvao svoju samostojnost ili nije? Je li možda uništen. Opstoji li zajedno s onim što pokazuje ili je preobražen? O svemu tome ne saznajemo ništa. No, to su presudna pitanja za shvaćanje euharistije, kako ćemo vidjeti kasnije. Drugo, Marionova fenomenologija euharistije naglašava da se u euharistiji pojavljuje Kristova kenoza na križu. No, postavlja se i dalje pitanje što nam se tu daje. Ako se daje sam Krist, onda ostaje otvoreno na koji način se on tako daje da ipak ne pijemo i jedemo njega samoga. A ako se ne daje on sam, onda se pita što se to daje a da nije Krist. Tako nas Marionova teorija ne vodi naprijed, nego samo vraća već poznatim srednjovjekovnim prijeporima koji su i doveli do nauka o transsupstancijaciji. ${ }^{11}$

Nakon kratke analize Marionove kritike, možemo se posvetiti analizi katoličkoga nauka o transsupstancijaciji, posebno imajući u vidu problematiku štovanja Kristove krvi u ludbreškom i u drugim svetištima. ${ }^{12}$ Prema Josephu

9 Isto, str. 153.

10 Vidi I. Žižić, Fenomenologija i teologija. Fenomenološki vidovi euharistije Jeana-Luca Mariona, u: Filozofska istraživanja 27 (2007), sv. 2., str. 337-356 (posebno str. 344-351). Također N. Reali, Fino all'abbandono. L'eucaristia nella fenomenologia di Jean-Luc Marion, Roma, 2001.

11 U novije vrijeme njemački filozof Robert Spaemann također kritizira nauk o transsupstancijaciji, jer on stvara dojam da postoji neka supstancija kruha neovisno o čovjekovu svijetu značenja. Spaemann predlaže da se pojam transsupstancijacije zamijeni pojmom »supstancijacije«. Prema Spaemannu, pojam supstancije podrazumijeva svrhovitost, određenu težnju. Pod tim vidom neživa bića, a to je primjerice kruh, nemaju uopće supstanciju, ne poznaju nikakvu težnju, svrhovitost, »ne teže ni za čim«, ravnodušni su spram nas. U euharistiji pak kruh dobiva »supstanciju « Kristova tijela, tj. nastaje supstancijacija kruha, on sada »želi« da ga se jede, dakako kao Kristov kruh. Usp. R. Spaemann, »Supstancijacija«. O ontologiji euharistijske pretvorbe, u: Communio 40 (2014) br. 120, str. 144-146. No, i s tom se teorijom ne možemo složiti. Spaemann ne uviđa da se i neživa bića, ako su umjetna ili proizvedena, kao što je kruh, imaju supstanciju, ukoliko im čovjek stvara ili pridaje supstanciju, težnju, svrhovitost. Premda se supstancije neživih bića razlikuju od živih, i ta neživa, proizvedena bića imaju svoju supstanciju, samostojnost i svoju težnju, a ne samo značenje. U tom smislu kruh nije »ravnodušan« spram značenja unutar čovjekova svijeta. U euharistiji sada to samostojno i svrhovito kruha postaje drugom supstancijom, supstancijom Isusa Krista.

12 Od mnogobrojne literature o transupstancijaciji izdvajamo samo sljedeće: J. Wohlmuth, Realpräsenz und Transsubstantiation im Konzil von Trient. 2 Bde., Bern — Frankfurt 1975. Isti, Noch 
Ratzingeru, pojam supstancija označava metafizičku, predfizikalnu i nefizikalnu stvarnost, ${ }^{13}$ kod koje se »ne misli na 'kvante', nego na duboki, istinski temelj bitka «. ${ }^{14}$ Riječ je, prema teološkom shvaćanju, o samostojnosti koja pripada svakomu biću, tj. o njegovoj autonomiji. Stoga transsupstancijacija nije fizikalno događanje, nego označava pretvorbu, preobrazbu supstancije bića - kruha i vina, njihove samostojnosti u supstanciju Isusa Krista. Na taj način kruh i vino u euharistiji postaju »potpuni znakovi « njegove prisutnosti. ${ }^{15}$ Pritom, prema katoličkom nauku, supstancija kruha i vina ne biva uništena, jer bi se time zanijekala pozitivnost stvorenja (teorija anihilacije). Stoga Crkva govori o pretvorbi, a ne o uništenju supstancije kruha i vina (DH 700; 802; 1652). S druge pak strane, njihove supstancije ne opstoje jednostavno jedna pokraj druge, što bi značilo da se u euharistiji uopće ne susreće sama supstancija Isusa Krista (teorija konsupstancijacije i impanacije - DH 1652). ${ }^{16}$ Naprotiv, supstancija kruha i vina je očuvana, ali tako pretvorena i preobražena da postoji samo jedna supstancija, a to je supstancija tijela i krvi Kristove. Ovdje ne ćemo ulaziti u daljnje pojašnjenje nauka o transsupstancijaciji. Ono što je često promiče u teološkim promišljanjima o transsupstancijaciji jest eshatološki naboj toga pojma. Naime, Tridentski sabor naučava da se »u presvetom sakramentu euharistije uistinu, stvarno i bitno nalazi tijelo i krv Gospodina našega Isusa Krista, zajedno s dušom i božanstvom, pa dosljedno čitav Krist«(DH 1651). Dakle, u euharistiji je prisutan čitav Krist, i to uistinu, stvarno i bitno: vere, realiter et substantialiter. No, u euharistiji nije prisutan Isus Krist u vidljivosti, odnosno historijski Krist. Toma Akvinski tvrdi da je $\mathrm{u}$ euharistiji Krist prisutan in specie sacramenti, ali ne in propria specie. ${ }^{17}$ Time se želi reći da je doduše prisutan cijeli Krist, njegova supstancija, ali ne Isus Krist u

einmal: Transsubstantiation oder Transsignifikation, u: ZKTH 97 (1975), str. 430-440; N. Slenczka, Realpräsenz und Ontologie. Untersuchungen der ontologischen Grundlage der Transsignifikationslehre, Göttingen 1993.; D. Sattler, Wesensverwandlung. Zur bleibenden Bedeutung der Rede von »Transsubstantiation « in einer ökumenischen Eucharistielehre, u: Theologie der Gegenwart 42 (1999), str. 131-142; Th. Freyer, Transsubstantiation versus Transfinalisation/Transsignifikation? Bemerkungen zu einer aktuellen Debatte, in: Catholica 49 (1995), str. 174-195.; G. Hinzen, Personale und sakramentale Gegenwart des Herrn in der Eucharistie. Zu Notger Slenczkas Buch 'Realpräsenz und Ontologie', in: Catholica 47 (1993), str. 210-237; H.-J. Schulz, 'Wandlung' im ostkirchlich-liturgischen Verständnis. Eine Orientierung im Disput um Transsubstantiation und Transsignifikation, u: Catholica, 40 (1986), str. 270-286; A. Starić, Teološko tumačenje euharistijske Kristove prisutnosti, u: Bogoslovska smotra, 2-3 (1981), str. 239-255.

13 J. Ratzinger, Das Problem der Transsubstantiation und die Frage nach dem Sinn der Eucharistie, u: ThQ 147 (1967), str. 129-158 (str. 148).

14 J. Ratzinger, Bog je s nama. Euharistija: središte života, Split, 2005, str. 88.

15 J. Ratzinger, Das Problem der Transsubstantiation und die Frage nach dem Sinn der Eucharistie, str. 152. Također Bog je s nama. Euharistija: središte života, str. 89s.

16 Ratzinger naglašava da se pojam transsupstancijacije ne treba nužno shvaćati u suprotnosti s teorijom konsupstancijacije, ako se pod tim podrazumijeva da i kruh i vino, kao fizikalno-kemijske stvarnosti, i dalje nastavljaju postojati. No, jednostavno stajanje jedne supstancije pokraj druge, gdje bismo govorili o dvjema supstancijama u euharistiji, teološki je neprihvatljivo (Isto, str. 153). Više o tome J. H. Tück, Gabe der Gegenwart. Theologie und Dichtung der Eucharistie bei Thomas von Aquin, Freiburg — Basel — Wien, 2009, str. 69-111.

17 Toma Akvinski, S.th. III, q. 73, a. 5 c. 
svojoj vidljivoj i proslavljenoj tjelesnosti. Još ne gledamo proslavljenoga Isusa Krista, on nam je još skriven. Ipak, dana nam je njegova supstancija, ono što on jest u sebi, tj. cijelo njegovo biće, božanstvo, duša i tijelo. Tako pojam supstancije u sebi krije dvostruko značenje. S jedne strane, izriče stvarnu Kristovu prisutnost, njegov istinski bitak. Mogli bismo reći da izriče ono najbitnije, jer čemu vrijedi imati izvanjsko bez onoga što je jezgra svake osobe, pa tako i Isusa Krista. S druge pak strane, supstancija ukazuje na bolan nedostatak, na »još ne «, na ono što će se tek ostvariti na koncu vremena. Hugo od sv. Viktora vrlo lijepo opisuje tu eshatološku napetost $\mathrm{u}$ euharistiji. On se pita koliko dugo traje supstancijalna prisutnost $\mathrm{u}$ euharistiji. Zaključuje da onoliko dugo traje koliko mi osjećamo osjetilom okusa kruh i vino. Krist je stvarno prisutan, ali kratkotrajno u nama, kako bismo nastavili čeznuti za njim i kako bismo njegovali duhovno zajedništvo s njime. ${ }^{18}$

\section{Ikoničko štovanje Predragocjene Krvi Kristove i euharistija}

Nakon što smo ukratko prikazali nauk o transupstancijaciji, sada se možemo posvetiti teološkim promišljanjima o krvi Kristovoj. Ona će nam poslužiti da pokušamo dogmatsko-teološki sagledati bit i važnost štovanja krvi Kristove.

Slobodno možemo reći da je kasno srednjovjekovlje razdoblje krvi Kristove par excellence. ${ }^{19}$ Nikada se u Crkvi nije toliko štovala krv Kristova koja se čuvala u svetištima širom Europe. Bilo da se krv Kristova u svetištima shvaćala kao krv koju je, prema predaji, sačuvao vojnik Longin, koji je probo Isusu bok, bilo da je bila riječ o krvi Kristovoj koja se čudesno pojavila na hostiji ili umjesto vina, kao što je to slučaj u Ludbregu, krv Kristova središte je ne samo života Crkve, nego mnogobrojnih teoloških rasprava. ${ }^{20}$ Vrlo suptilne i složene teološke prijepore pokušat ćemo prikazati pojednostavljeno. Rastuća pobožnost Krvi Kristove u 14. i 15. stoljeću nametnula je pitanje ondašnjim teolozima, odnosno dvjema

$18 \gg$ Sic ergo in sacramento suo modo temporaliter venit ad te et est corporaliter tecum ut per corporalem presentiam ad spiritualem quarenda exciteris et inveniendam adiuveris. Quando in manibus sacramentum eius tenes corporaliter tecum est. Quando ore suscipis corporaliter tecum est. Quando manducas et quando gustas corporaliter tecum est. Denique in visu in tactu in sapore corporaliter tecum est. Quamdiu sensus corporaliter afficitur, presentia corporaliter non aufertur. Postquam autem sensus corporalis in percipiendo deficit, deinceps corporalis presentia querenda est sed spiritualis retinenda. Dispensatio completa est, perfectum sacramentum, virtus manet, christus de ore ad cor transit. Melius est tibi tu eat in mentem tuam quam in ventrem tuum. Cibus iste animae non corporis est.«(De sacramentis Christianae fidei II, 8, XIII; izd. R. Berndt SJ, Aschendorff, 2008.)

19 Mnogobrojni su razlozi kasnijega nestanka štovanja krvi Kristove. Navest ćemo samo neke: zlouporabe štovanja, protestantska kritika relikvija, utjecaj racionalizma i prosvjetiteljstva na katoličku liturgiju itd.

20 Opširnije o tome: C. W. Bynum, Wonderful Blood. Theology and Practice in Late Medieval Northern Germany and Beyond, Philadelphia, 2007.; N. da Terrinca, La devozione al Preziosissimo Sangue di nostro Signore Gesù Cristo: Studio storico teologico a proposito di un trattato inedito di S. Giovanni da Capestrano, Roma, 1969.; P. Dinzelbacher, Das Blut Christi in der Religiosität, u: N. Kruse - H. U. Rudolf (prir.), 900 Jahre Heilig-Blut Verehrung in Weingarten 1094-1994. Festschrift zum Heilig-Blut-Jubiläum am 12. März 1994., Jan Thorbecke, Sigmaringen, 1994, str. 415-434. 
najvažnijim teološkim školama, dominikanskoj i franjevačkoj, kako shvaćati krv Kristovu u svetištima. Dominikanska škola polazila je od toga da je Isus Krist hipostatski sa sobom sjedinio svu krv, tako da je s uskrsnućem svu krv ponio u vječno zajedništvo s Ocem. ${ }^{21}$ Premda Toma Akvinski svojim promišljanjima ostavlja mogućnost prisutnosti krvi Kristove na zemlji, ${ }^{22}$ dominikanska se teologija u cijelosti odnosi suzdržano ili isključujuće prema mogućnosti stvarne prisutnosti krvi Kristove na zemlji. Franjevačka teologija pak polazi od toga da nije sva krv Kristova hipostatski sjedinjena s Logosom. Naime, franjevački teolozi razlikuju dvije forme, dušu i tjelesnost (forma corporeitatis). Budući da krv ne pripada formi tjelesnosti, ona se ne nalazi sjedinjena hipostatski s Logosom. U tom smislu franjevački teolozi računaju s mogućnošću da je krv Kristova mogla ostati na zemlji, ali nije riječ o hipostatski sjedinjenoj krvi Kristovoj, tako da se tu krv u strogom smislu ne može štovati. U tom smislu i jedna i druga škola bila je suzdržana i gotovo negativno raspoložena prema štovanju krvi Kristove. Dugotrajne rasprave prekinuo je papa Pio II. te ostavio otvorenim pitanje je li krv Kristova bila sjedinjena hipostatski s Logosom ili nije: »Apostolskom vlašću određujemo i ovim pismom naređujemo, da se nitko od spomenute braće (manje braće i braće propovjednika) o gornjoj dvojbi ne usudi ponovno raspravljati, propovijedati, javno ili privatno govoriti, ili drugima savjetovati, kao da je naime krivovjerno ili grješno držati ili vjerovati, da je sama presveta krv istog Gospodina našega Isusa Krista, (kao što se misli) za vrijeme trodnevlja muke bila na bilo koji način odijeljena ili odvojena od samog boštva, ili da nije bila, dok Mi i Apostolska stolica o toj dvojbi ne odredimo što treba štovati« (DH 1385). S obzirom na krv Kristovu, papa Pavao II. je u buli naslovljenoj Opatu sv. Marije u biskupiji Saintes u Francuskoj prihvatio promišljanje pariškoga teološkog fakulteta koji glasi: »Non repugnat pietati fidelium credere, quod aliquid de sanguine Christi effuso tempore passionis remanserit in terris. $\ll^{23}$ — Kršćanskoj se pobožnosti ne protivi vjera da je nešto od krvi Kristove, koja je prolivena u njegovoj muci, ostalo na zemlji.« Time je učinjen kompromis koji je uzeo u obzir nakanu jedne i druge teološke škole: dominikanci su morali prihvatiti da je nešto krvi moglo ostati na zemlji, a franjevci da se tu krv s pravom može i treba štovati.

Imajući u vidu tu papinsku odluku i navedene rasprave, štovanje Kristove krvi na zemlji može se teološki promotriti na sljedeći način:

1. Premda se Crkveno učiteljstvo još nije očitovalo o dvojbi oko toga je li Kristova krv za vrijeme trodnevlja muke bila odijeljena ili ne, danas bismo mirno mogli reći s franjevačkom teologijom da je prolivena krv Kristova u trodnevlju muke ostala na zemlji, uostalom kao i ostali dijelovi Kristova tijela, primjerice Kristov prepucij. Isto tako, s dominikancima možemo

21 Toma Akvinski STh III, 54, 2: »Totus sanguis qui de corpore Christi fluxit, cum ad veritatem humanae naturae pertineat, in corpore Christi resurrexit.«

22 Toma Akvinski, Questiones quodlibetales 5, 3, 1. Opširnije o tome: C. W. Bynum, Wonderful Blood, str. 102s.

23 M. D. Chenu, Sang du Christ, u: Dictionnaire de Théologie Catholique, XIV/1., str. 1096. 
reći da je Krist uskrsnuo s preobraženom krvlju, tj. s onom koja je ostala i bila u njegovu mrtvom tijelu.

2. Kako je papa Pavao II. naznačio, teologija mora računati s mogućnošću prisutnosti istinske krvi Kristove na zemlji. No, je li to krv hipostatski s Kristom sjedinjena ili ne, o tome Crkveno učiteljstvo nije dalo svoje mišljenje. Općenito je mišljenje teologa, napose srednjovjekovnih, da ta krv nije hipostatski sjedinjena s Logosom. To znači da krv Kristovu treba shvaćati kao »relikviju«. Ta je relikvija mogla biti prenesena od prvih početaka Crkve do dana današnjega (svetište u Mantovi) ili se čudesno pojavila na hostiji, u kaležu ili drugim objektima (svetište u Ludbregu).

3. Konkretno se u buli pape Lava X. o ludbreškom svetištu iz 1512. godine nigdje ne spominje krv Kristova. ${ }^{24}$ Govori se o tekućini, ali se nigdje niti ne niječe da je riječ o krvi Kristovoj. Ni kod ostalih svetišta Predragocjene Krvi Kristove nigdje Crkva izričito ne tvrdi da je prisutna krv Kristova, što je pak uobičajeni način govora Crkve o određenim čudima, a posebno glede Kristovih relikvija. Crkva je oprezna, ali ne niječući mogućnost prisutnosti krvi Kristove i dopuštajući pobožnost u određenom svetištu, prešutno je priznata prisutnost Krvi Kristove. ${ }^{25}$ Osim toga, treba uzeti u obzir i sensus fidelium, odnosno višestoljetnu pobožnost prema krvi Kristovoj u Ludbregu, koja je također vrlo važan (ne jedini) kriterij vjerodostojnosti govora o prisutnosti Predragocjene Krvi Kristove u Ludbregu i na drugim mjestima.

4. Budući da je Kristova krv na zemlji relikvija koju je Krist ili ostavio na zemlji nakon svoje smrti ili posebnim čudom uprisutnio (Ludbreg), značenje njezina štovanja treba tražiti upravo u teologiji relikvija. O relikvijama se može analoški ${ }^{26}$ razmišljati na način teologije ikone, tako da bismo ih mogli nazva-

24 Vidi http://www.svetiste-ludbreg.hr/dogadjaj-pretvorbe-krvi-kristove.html (pristupljeno 28. siječnja 2016.)

25 Netko bi mogao pomisliti kako bi bilo zanimljivo i korisno analizirati DNK svih »tekućina« u svetištima Predragocjene Krvi Kristove u Crkvi. No, taj je zahtjev teološki besmislen. Naime, nitko ne zna koji je stvarni DNK Kristove krvi, tako da analiza ne bi ničemu koristila, osim puke znatiželje (da se ustanovi razlika ili jednakost DNK postojećih »tekućina«) koja je ovdje teološki neutemeljena. Isto tako treba reći da čudo Predragocjene Krvi Kristove ne može promatrati u kontekstu teologije tzv. privatnih objava. U strogom teološkom smislu, privatne objave odnose se uvijek na određenu poruku, izjavu ili misao koju Isus Krist ili BDM priopćava vjerniku te koja ima značenje pojedinca vjernika ili za samu Crkvu. Kod čuda Predragocjene Krvi Kristove nemamo nikakvu konkretnu izjavu, misao i poruku Isusa Krista, nego samo čudo. Stoga Crkva s pravom ne govori o »objavi« Isusa Krista u svetištima njegove krvi. Dakako, ono što je zajedničko čudu Predragocjene Krvi Kristove u Ludbregu i privatnih objava jest njihov neobvezujući karakter (od vjernika se ne zahtijeva fides divina), ali i golemo teološko-duhovno značenje za život Crkve u konkretnom povijesnom razdoblju. O privatnim objava: I. Raguž, »Malena vrata « u široka prostranstva Trojedinoga Boga. O privatnim objavama i ukazanjima Blažene Djevice Marije, u: Vjesnik Đakovačko-osječke nadbiskupije i Srijemske biskupije 11-12 (2008), str. 961-966.

26 Naglašavamo analoški odnos relikvije i ikone, jer relikvija krvi Kristove predstavlja teološki relevantniju stvarnost od ikone. Ono što Kristovu relikviju razlikuje od ikone jest čudo prisutnosti određenoga dijela Kristova tijela. Sličnost između Kristove relikvije i ikone jest u njihovu simboličkom značenju, omogućivanju i ozbiljenju relacije Boga i čovjeka. 
ti ikoničkim stvarnostima. ${ }^{27} \mathrm{U}$ svojem temeljnom teološkom značenju ikona ima ulogu relacije..$^{28}$ Ona nas stavlja u relaciju s Isusom Kristom. Njezina vidljivost i materijalnost ukazuje na vidljivost i materijalnost samoga Boga, koji se utjelovio u Isusu Kristu. Ovako piše Teodor Studit, veliki branitelj ikona u 8. stoljeću: »Slika je za nas sveto svjetlo, spasonosan spomenik, jer nam pokazuje Krista u njegovu rođenju i krštenju, Krista koji čini čudesa, Krista u grobu, Krista koji uskršava i ulazi na nebo. U svemu tome ne bivamo prevareni, kao da se sve to nije dogodilo. Jer gledanju pritječe u pomoć duhovno promatrane, tako da oboje jača našu vjeru u otajstvo spasenja. «29 U kontekstu teologije ikone mogli bismo reći da štovanje krvi Kristove ima ulogu stavljanja vjernika u relaciju s Isusom Kristom. Krv Kristova podsjeća vjernike na cijenu našega otkupljenja, odnosno na ljubav koju nam je Bog u Isusu Kristu iskazao. Bog je toliko ljubio svijet da nije prezao od toga da i svoju krv prolije za nas: »Njega je Bog izložio da svojom krvlju bude Pomirilište po vjeri« (Rim 3, 25). Vjera u Isusa Krista nije vjera u neki bestjelesni »nagi Logos«, nego u utjelovljeni Logos koji je i sada istinski, stvarno i supstancijalno sjedinjen s čovještvom.

5. Kršćanska tradicija relikvijama i ikonama pripisivala je veliku važnost. No, pritom se razlikuje između cultus duliae i cultus latriae (2. nicejski sabor 787. - DH 601). Relikvijama pripada samo cultus duliae, odnosno štovanja, ali ne i klanjanja. Premda krv Kristova pripada relikvijama, teološka je tradicija Kristovim relikvijama pripisivala posebno značenje, tako da se njima iskazuje cultus latriae, kult klanjanja, jer je riječ o posebnim, tj. Kristovim relikvijama. Dakako, riječ je o kultu klanjanja ne u apsolutnom, nego samo u relativnom smislu, jer apsolutno klanjanje pripada samomu Bogu. ${ }^{30}$

6. Naposljetku, štovanje krvi Kristove, ako se ispravno liturgijski slavi ${ }^{31}$ i ako je slobodna od zlouporaba, ${ }^{32}$ služi slavlju euharistije. Time se vraćamo na naša početna razmišljanja o supstanciji. Naglasili smo da nam se u euharistiji daje cijela supstancija Isusa Krista, njegovo božanstvo i čovještvo. Dana nam je supstancija, ali ga još ne gledamo licem u lice, još ga ne vidimo kakav jest, u svojoj proslavljenoj tjelesnosti. Stoga štovanje krvi Kristove ima vrlo važnu eshatološku dimenziju. Oslobađa od opasnosti

27 Walter Kasper također smješta štovanje krvi Kristove u kontekst teologije ikone. Vidi W. Kasper, Der bleibende Gehalt der Heilig-Blut-Verehrung aus theologischer Sicht, u: N. Kruse - H. U. Rudolf (prir.), 900 Jahre Heilig-Blut Verehrung in Weingarten 1094-1994., str. 377-386 (str. 384s).

28 O teologiji ikone vidi Ch. Schönborn, L’icona di Cristo. Fondamenti teologici, Cinisello Balsamo, 1988; Bog posla sina svoga. Kristologija, Zagreb, 2008, str. 147-153; R. Hoeps (prir.), Bild-Konflikte, I, Schöningh, Paderborn — München — Wien — Zürich, 2007.

29 Ch. Schönborn, Bog posla sina svoga. Kristologija, str. 153.

30 Vidi J. Pohle - J. Gummersbach, Lehrbuch der Dogmatik II, Paderborn, ${ }^{10} 1956$, str. 465, 480.

31 Vidi W. Gross, Die Verehrung des Blutes Christi in der Liturgie der Gegenwart, u: N. Kruse H. U. Rudolf (prir.), 900 Jahre Heilig-Blut Verehrung in Weingarten 1094-1994., str. 387-413.

32 Vidi B. Schmied, Katholische Aufklärung und Heilig-Blut-Verehrung: das Anliegen Wessenbergs, u: N. Kruse - H. U. Rudolf (prir.), 900 Jahre Heilig-Blut Verehrung in Weingarten 10941994., str. 501-518. 
magijsko-fetišističkoga shvaćanja euharistije i ostalih sakramenata. Upozorava nas da Boga još ne posjedujemo, da smo još na putu, da i dalje trebamo čeznuti za njim. Krv Kristova već nas sada uvježbava na eshatološko stanje, kada ne ćemo više morati blagovati supstanciju Isusa Krista, nego ćemo ga gledati i ljubiti svim svojim bićem. Jednom riječju, Predragocjena Krv Kristova uči nas eshatološkoj napetosti. S druge pak strane, kako nije riječ o krvi hipostatski sjedinjenoj s Logosom, krv Kristova ne sjedinjuje nas sa supstancijom Isusa Krista. Stoga krv Kristova upućuje na supstanciju Isusa Krista, a to je euharistija. Štovanje krvi Kristove bez euharistije Boga bi udaljilo sa zemlje, onemogućilo bi stvarnu preobrazbu čovjeka ovdje i sada na zemlji, njegovo sjedinjenje već sada s Isusom Kristom. ${ }^{33}$ Parafrazirajući zaključke 2. nicejskog sabora o ikonama (DH 601), mogli bismo reći da »pozdrav ${ }^{34}$ i štovanje «Predragocjene Krvi Kristove pomaže nam u sljedećem: što češće budemo promatrali taj prikaz, to češće ćemo biti potaknuti da se sjetimo Isusove ljubavi prema nama, da čeznemo za njim.

On the Theology of Veneration of Relics of the Most Precious Blood of Christ Ivica Raguž*

\section{Summary}

The article expounds the theology of veneration of relics of the Most Precious Blood of Christ in the Croatian shrine at Ludbreg and also in other shrines of the Catholic Church. The Catholic teaching on transubstantiation is of great importance for a theological understanding of the devotion to the Blood of Christ. Therefore, the first part of the article presents the teaching on transubstantiation whereby some critical reflections are examined, but a different approach to this teaching as well, as propounded by the French philosopher, Jean-Luc Marion. The second section deals with particular theological theories on the Blood of Christ, followed by a concise summation of the theology of veneration of the Blood of Christ which assigns the veneration of the Blood of Christ to the theology of the icon. In this account of contemporary iconical veneration of the Blood of Christ in Ludbreg and other shrines, we assert the importance thereof for an understanding and living of the Eucharist.

Key words: transubstantiation, Blood of Christ, Jean-Luc Marion, Eucharist, Ludbreg

33 O političkim i drugim konotacijama nauka o transupstancijaciji vidi T. Ruster, Wandlung: ein Traktat über Eucharistie und Ökonomie, Osfildern, 2006.

34 Izraz »pozdrav« (aspasmos) u tekstu Koncila izriče eshatološku dimenziju. Pozdrav je uvijek početak. Početak koji može završiti razdvajanjem, jer pozdrav može biti usputan. No, pozdrav može biti početak koji mijenja i uvodi u dublje zajedništvo.

* Associate Professor Ivica Raguž, Ph.D., The Catholic Faculty of Theology in Đakovo. The Josip Juraj Strossmayer University of Osijek. Address: Petra Preradovića 17, p. p. 54, 31000 Osijek, Croatia. E-mail: ivica.raguz@os.t-com.hr 